\title{
Genetic Mapping in Methylophilus methylotrophus AS1
}

\author{
By A. T. MOORE, M. NAYUDU AND B. W. HOLLOWAY* \\ Department of Genetics, Monash University, Clayton, Victoria 3168, Australia
}

(Received 27 July 1982; revised 28 September 1982)

\begin{abstract}
Prime plasmids have been isolated from Methylophilus methylotrophus AS1 using the IncP-1 plasmid pMO172. Such plasmids can complement mutant function when transferred to appropriate strains of Pseudomonas aeruginosa PAO. From the range of particular functions complemented by each prime plasmid, a preliminary map of the $M$. methylotrophus AS1 genome with four groups of linked markers was obtained. Physical examination of two of these prime plasmids showed that each had acquired an additional DNA segment. Southern hybridization experiments showed there was sequence homology between the additional DNA segments and $M$. methylotrophus AS1 DNA, confirming that these prime plasmids carried a segment of the $M$. methylotrophus AS1 genome. Mapping by complementation may be applicable to other bacteria in which mutants suitable for selecting recombinants are not readily available.
\end{abstract}

\section{INTRODUCTION}

There is an increasing interest in genetic studies of bacteria other than those traditionally used (Levinthal, 1974), because of the availability of plasmids with chromosome-mobilizing ability in a variety of species (Holloway, 1979) and the need for genetic manipulation of bacteria used in biotechnology. The development of a conventional genetic recombination system in bacteria involves the use of an effective chromosome mobilization agent, the construction of multiply marked strains and a means of selecting rare recombinants. Methylophilus methylotrophus AS1 is a Gram-negative bacillus capable of growth on methanol as sole carbon source. It is used by Imperial Chemical Industries for the commercial production of 'Pruteen', a dried protein, animal feed additive. Our attempts to isolate an adequate range of auxotrophically marked strains of $M$. methylotrophus were unsuccessful, in agreement with the results of O'Connor \& Hanson (1978) who found that auxotrophs of methylotrophs are difficult to isolate.

Enhanced chromosome mobilizing (ECM) plasmids such as R68.45 are able to generate plasmid primes in a variety of bacterial genera (reviewed by Holloway, 1979). Primes carrying fragments of chromosomal DNA from Pseudomonas putida, Escherichia coli and Rhizobium spp. can complement the phenotype of $P$. aeruginosa mutants to produce a wild-type phenotype (Holloway et al., 1980; Johnston et al., 1978; Nagahari et al., 1977; Morgan, 1982; J. Barton \& A. Morgan, unpublished). Although ECM plasmids such as R68.45 can promote chromosome transfer in $M$. methylotrophus AS1, the frequency of recombinants and the range of suitable selective mutants are inadequate for an effective mapping system to be established (Holloway, 1981). Accordingly we set out to establish an alternative system of mapping, which we have called complementation mapping. An ECM plasmid was used to generate a library of prime plasmids carrying fragments of the $M$. methylotrophus ASl genome. The genes carried by these primes were identified by complementation after transfer to suitably marked $P$. aeruginos $a$ PAO strains. The prime plasmids were further tested for their ability to complement a range of $P$. aeruginosa mutants to indicate which genes were carried by an individual prime and hence linked on the $\boldsymbol{M}$. methylotrophus genome. A preliminary account of this work was presented at the Fourth International Symposium on Genetics of Industrial Microorganisms (in Kyoto in 1982). 
Table 1. Strains used in this study

All P. aeruginosa strains were derived from PAOl (Holloway, 1969). The full genotypes of strains referred to in Table 3 are given below. Details of other strains listed in Table 2 and others used in this investigation are available from the authors.
Strain Genotype/Phenotype*
Derivation $\dagger$
Reference

Pseudomonas aeruginosa

PAO5 trp-54 rif-5 fon-1

Spontaneous rifampicin resistant derivative Holloway Collection of PAO3

PAO12 pur-136 leu-8 chl-3

PAO90 his-67 str-9

PAO114 pyrD48 chl-2

PAO129 pyrB52 chl-2

PAO286 met-28 trp-6 chl-2

PAO305 argG27 chl-2

PAO325 argB18 lys-57 chl-2

PAO462 trpAl

$\mathrm{PAO} 470$ trpDI

PAO472 trpEI

PAO503 met-9011

PAO896 pur-136 chl-3

PAO897 leu-8 chl-3

PAO898 ilv-202 str-1

PAO899 met-28 str-1

PAO900 ilvB/C208

$\mathrm{PAO} 904$ argF10

PAO907 proA54

PAO1086 proB64 str-93

Pseudomonas putida

PPN1089 cys-401 trp-405

Escherichia coli

JP2314 trpE365 pyrF40 $\mathrm{F}^{-}$

Methylophilus methylotrophus

AS1 Wild type

Plasmids

R68.45 IncP-1 $\mathrm{Cb}^{\mathrm{r}} \mathrm{Km}^{\mathrm{r}} \mathrm{Tc}^{\mathrm{r}} \mathrm{Cma}^{+}$

pMO61 IncP-1 $\mathrm{Cb}^{r} \mathrm{Km}^{r} \mathrm{Tc}^{r} \mathrm{Cma}^{+}$

pMO172 IncP-1 $\mathrm{Cb}^{r} \mathrm{Km}^{\mathrm{r}} \mathrm{Tc}^{\mathrm{r}} \mathrm{Cma}^{+}$

pur leu derivative of $\mathrm{PAO} 1$, intermediate

strain lost, NG

Spontaneous streptomycin-resistant Holloway Collection

derivative of a histidine auxotroph, strain

since lost, NG

pyr derivative of PAO1, NG

pyr derivative of $\mathrm{PAO} 1, \mathrm{NG}$

met trp derivative of $\mathrm{PAO} 1, \mathrm{MC}$

arg derivative of $\mathrm{PAOl}, \mathrm{NG}$

Issac \& Holloway (1968)

lys derivative of PAO303

Holloway Collection

Isaac \& Holloway (1972)

trpE1 (old terminology) derivative of PAOl Calhoun et al. (1973)

$\operatorname{trpBI}$ (old terminology) derivative of PAO1 Calhoun et al. (1973)

trpA I (old terminology) derivative of PAO1 Calhoun et al. (1973)

Transductant (E79tv-2) of PAO1817

Holloway Collection

leu- $8^{+}$transductant (E79tv-2) of PAO12

pur-136+ transductant (E79tv-2) of PAO12

met $-28^{+}$transductant (E79tv-2) of PAO8

Morgan (1982)

Morgan (1982)

Morgan (1982)

$i l v-202^{+}$transductant (E79tv-2) of PAO8

trpB4+ $4^{+}$transductant (E79tv-2) of PAO422

leu- $10^{+}$transductant (E79tv-2) of PAO25

cys-5605+ his-5075+ transductant (E79tv-2)

Holloway Collection

Morgan (1982)

Morgan (1982)

Spontaneous streptomycin resistant mutant Holloway Collection of PAO888

cys-401 trp-405 $\mathrm{arg}^{+}$derivative of PPN1088 A. Boronin \& A. Morgan, unpublished

J. Pittard, unpublished

ICI Strain Collection

Haas \& Holloway (1976)

Riess et al. (1980)

Holloway Collection

Krishnapillai (1971)

F116L General transducing phage

G101 General transducing phage

E79tv-2 General transducing phage

Mutant of virulent phage E79
(1968)

Morgan (1979)

* The following designations have been used. Anabolic markers: arg, arginine; cys, cysteine; his, histidine; ilv, isoleucine, valine; leu, leucine; lys, lysine; met, methionine; pro, proline; pur, purine; pyr, pyrimidine; ser, serine; thr, threonine; and trp, tryptophan. Resistance markers: chl, chloramphenicol; fon, phage F116L; rif, rifampicin; $s t r$, streptomycin. Plasmid characters: $\mathrm{Cb}^{r}$, carbenicillin resistance; $\mathrm{Km}^{r}$, kanamycin resistance; Tc ${ }^{r}$, tetracycline resistance; $\mathrm{Cma}$, chromosome-mobilizing ability.

$\dagger$ Unless otherwise stated, all mutants were obtained after treatment of the parent strain indicated with ethyl methanesulphonate. NG indicates mutagenesis with $N$-methyl- $N^{\prime}$-nitro- $N$-nitrosoguanidine; MC indicates mutagenesis with manganous chloride. In cases where the strain has been previously published, further details of isolation can be obtained from the cited reference. 
Table 2. Strains of $P$. aeruginosa $P A O$ used to selec $k$ "id primes and to detect complementation by plasmid primes derived from $M$. methylotrophus $A S 1$

$$
\begin{aligned}
& \text { Map } \\
& \text { location }
\end{aligned}
$$

Marker $\quad(\mathrm{min}) \dagger$

$\begin{array}{lr}* \arg A & 18 \\ { }^{*} \arg B & 21 \\ \arg C & 35 \\ \arg F & 45 \\ \operatorname{argG} & 45 \\ { }^{*} \operatorname{argH} & 19 \\ \text { cys-54 } & 79 \\ { }^{*} \text { cys-59 } & 94 \\ \text { hisI } & 94 \\ { }^{*} \text { hisIIA } & 17 \\ { }^{*} \text { hisIIB } & 17 \\ { }^{*} \text { hisIII } & 16 \\ { }^{*} \text { hisIV } & 14 \\ \text { his } V & 30 \\ \text { ilvB } / C & 7\end{array}$

$\begin{array}{lr}\text { ilvD } & 31 \\ \text { leu-8 } & 42 \\ \text { leu-10 } & 53 \\ \text { lys-12 } & 20 \\ \text { met-28 } & 31 \\ \text { met }-9011 & 53 \\ \text { proA } & 39 \\ \text { proB } & 1 \\ \text { proC } & 32\end{array}$

$\begin{array}{lll}\text { pur-66 } & 42 & \text { Unknown (requires adenine for growth) } \\ \text { pur-70 } & 90 & \text { Unknown (requires adenine for growth) } \\ \text { pur-136 } & 25 & \text { Unknown (requires adenine for growth) } \\ \text { pyrB } & 32 & \text { Aspartate transcarbamylase } \\ \text { pyrD } & 57 & \text { Dihydroorotic acid dehydrogenase } \\ \text { pyrE } & 22 & \text { Orotidylic acid pyrophosphorylase } \\ { }^{*} \text { pyrF } & 59 & \text { Orotidine monophosphate pyrophosphorylase } \\ { }^{*} \text { ser-3 } & 27 & \text { Unknown (requires serine for growth) } \\ { }^{*} \text { thr-48 } & 43 & \text { Unknown (requires threonine for growth) } \\ \text { trpA } & 27 & \text { Tryptophan synthase } \alpha \text {-activity } \\ \text { trpB } & 27 & \text { Tryptophan synthase } \beta \text {-activity } \\ \text { trpC } & 34 & \text { Indoleglycerolphosphate synthase } \\ \text { trpD } & 34 & \text { Anthranilate phosphoribosyltransferase } \\ \text { trpE } & 34 & \text { Anthranilate synthase } \\ \text { trpF } & 54 & \text { Phosphoribosyl anthranilate isomerase }\end{array}$

$N$-Acetylglutamate synthase

$N$-Acetylglutamate 5-phosphotransferase

$\mathrm{N}$-Acetylglutamate 5-semialdehyde dehydrogenase

Anabolic ornithine carbamoyltransferase

Argininosuccinate synthetase

Argininosuccinase

Unknown (requires cysteine for growth)

Unknown (requires cysteine for growth)

Histidinol dehydrogenase

Unknown (requires histidine for growth)

Unknown (requires histidine for growth)

Unknown (requires histidine for growth)

Unknown (requires histidine for growth)

Unknown (requires histidine for growth)

ilv $B$ lacks acetohydroxy synthetase,

ilv $C$ lacks reductoisomerase

Dehydroxy acid dehydratase

Unknown (requires leucine for growth)

Unknown (requires leucine for growth)

Unknown (requires lysine for growth)

Unknown (requires methionine for growth)

Unknown (requires methionine for growth)

Glutamate 5-phosphotransferase

Glutamyl 5-phosphate reductase

Lacks ability to convert $\Delta^{1}$-pyrroline

Unknown (requires adenine for growth)

Orotidine monophosphate pyrophosphorylase

* No plasmid primes were isolated which complemented these markers.

† The map locations are those given by Holloway \& Crockett (1982).
Rifampicinsensitive $\begin{array}{ll}P . \text { aeruginosa } & \text { isogenic } \\ \text { PAO strain no. } & \text { strain no. }\end{array}$

$\begin{array}{rr}894 & 952 \\ 916 & 303 \\ 679 & 307 \\ 686 & 904 \\ 685 & 305 \\ 373 & 362 \\ 1155 & 944 \\ 1156 & 949 \\ 675 & 903 \\ 913 & \text { GMA } \\ 914 & 892 \\ 915 & 893 \\ 1152 & 891 \\ 919 & \text { GMA } \\ 930 & 900 \\ & \\ 920 & 898 \\ 925 & 897 \\ 687 & 905 \\ 895 & 372 \\ 680 & 286 \\ 926 & 503 \\ 682 & 907 \\ 911 & 888 \\ 679 & 906 \\ & \\ 684 & 901 \\ 688 & 909 \\ 917 & 12 \\ 681 & 129 \\ 928 & 114 \\ 486 & 483 \\ 929 & 161 \\ 678 & 2 \\ 683 & 908 \\ 918 & 462 \\ 677 & 467 \\ 921 & 468 \\ 922 & 470 \\ 923 & 472 \\ 927 & 474\end{array}$

\section{METHODS}

Strains. The strains of Methylophilus methylotrophus, Pseudomonas aeruginosa, Escherichia coli and Pseudomonas putida are listed in Table 1, as are the plasmids and bacteriophages used. Table 2 lists the P. aeruginosa mutations used.

Media. The media for P. aeruginosa were as described previously (Holloway, 1978; Pemberton \& Holloway, 1973; Royle \& Holloway, 1980). For $M$. methylotrophus the C2 medium of Windass et al. (1980) was used.

Isolation of plasmid primes from $M$. methylotrophus. The ECM plasmid used was pMO172, a derivative of pMO61 (Riess et al., 1980). pMO61 is a derivative of R68 with enhanced chromosome-mobilizing ability. pMO61 was transferred to $P$. putida and used to seek prime plasmids. pMO172 was one such derivative which originally demonstrated prime plasmid properties in $P$. putida, although these properties have since been lost (A. Morgan \& A. Boronin, unpublished). pMO172 was transferred to $M$. methylotrophus AS1. 
A 24 h culture of $M$. methylotrophus AS1(pMO172) was grown in liquid $\mathrm{C} 2$ medium, while a selected $P$. aeruginosa PAO strain was grown overnight at $43{ }^{\circ} \mathrm{C}$ in nutrient broth containing $0.4 \% \mathrm{KNO}_{3}$. Growth of such recipients at $43^{\circ} \mathrm{C}$ produces a restriction-deficient phenotype which enhances foreign DNA transfer into $P$. aeruginosa PAO (Holloway, 1965). A $5 \mathrm{ml}$ sample of each culture was filtered through a Gelman Metricel membrane filter $(47 \mathrm{~mm}$ diameter, pore size $0.45 \mu \mathrm{m})$ and the filter bearing the cells was placed on a warm $\left(37^{\circ} \mathrm{C}\right)$ $\mathrm{C} 2$ agar plate plus $0.4 \%$ glucose. The membranes were then incubated for $6 \mathrm{~h}$ at $37^{\circ} \mathrm{C}$ after which the bacteria were washed off in $2.5 \mathrm{ml}$ warm saline and vortexed vigorously to suspend the cells evenly. Samples were plated on appropriate selective media to identify transconjugants which had acquired a plasmid prime capable of complementing the auxotrophic mutation in the recipient PAO strain. The selective plates were incubated at $37^{\circ} \mathrm{C}$ for $3 \mathrm{~d}$ and any candidate colonies tested for the presence of plasmid primes carrying fragments of ASl chromosome.

Preparation of plasmid DNA. Plasmid DNA was prepared as described by Nayudu \& Holloway (1981). R68 and R68.45 were isolated from $E$. coli $\mathrm{K} 12$ strain JP2314. The ECM plasmids pMO61 and pMO172 were isolated from $P$. aeruginosa PAO8 and $P$. putida PPN1089. The prime plasmids pMO551 and pMO564 were isolated from $P$. aeruginosa $\mathrm{PAO} 5$ and PAO305 respectively.

Preparation of total bacterial DNA. Bacterial DNA was isolated from $M$. methylotrophus AS1 by the technique of Willetts et al. (1981).

Restriction enzyme and gel electrophoresis techniques. The techniques used were as described by Nayudu \& Holloway (1981) except that $\lambda$ HindIII and $\lambda H$ HindII/EcoRI fragments (New England Biolabs) were used as standards with the maximum error estimated to be $\pm 0.15 \mathrm{~kb}$.

Southern hybridization techniques. The Southern hybridization technique (Southern, 1975) was used with modifications as described by Willetts et al. (1981).

\section{RESULTS}

\section{Isolation and genetic characterization of prime plasmids}

Membrane matings were carried out to isolate prime plasmids of pMO172 carrying different fragments of AS1 chromosome, using different $P$. aeruginosa $\mathrm{PAO}$ auxotrophs as recipients and M. methylotrophus $\mathrm{AS1}(\mathrm{pMO172}$ ) as donor. The range of such primes isolated is listed below (Table 3). Exconjugant colonies which could result from the formation of prime plasmids were found at a frequency of about $10^{-8}$ per donor cell. As an example of a typical plasmid prime, let us take the isolation and characterization of pMO555. Methylophilus methylotrophus AS1(pMO172) was membrane mated to P. aeruginosa PAO286 (met-28 trpC) and the mating mixture subsequently plated on to minimal medium plus tryptophan. One colony was shown to be able to transfer $\mathrm{Met}^{+}$and carbenicillin resistance when mated to appropriate recipients. The transfer frequency of $\mathrm{Met}^{+}$was shown to be $3.0 \times 10^{-2}$ per donor cell. Selection for carbenicillin resistance showed a transfer frequency of this plasmid marker of $4.7 \times 10^{-3}$ per donor cell and all the exconjugants had also transferred the $\mathrm{Met}^{+}$phenotype. Kanamycin resistance and tetracycline resistance were also shown to be transferable. Three other auxotrophic functions were shown to be transferable, $\operatorname{trp} C\left(2.5 \times 10^{-2}\right.$ per donor cell), $\operatorname{trp} D\left(8.8 \times 10^{-3}\right)$ and $\operatorname{trp} E(1.8$ $\left.\times 10^{-2}\right)$. None of the other markers listed in Table 2 could be transferred at this frequency, but some were transferred at frequencies of $10^{-5}-10^{-6}$ per donor cell. This is presumed to be due to mobilization of chromosomal markers carried by PAO286 by the plasmid prime.

Both the $\operatorname{trpC}$ and met-28 mutant alleles were shown by transduction to be still present in PAO286(pMO555). With bacteriophage F116L grown on PAO286(pMO555), selection was made for $\operatorname{argC}^{+}$(using PAO307 as the recipient) on minimal medium plus tryptophan, and using PAO898 as a recipient, selection was made for $i l v D^{+}$on minimal medium plus methionine. Transduction frequency was about $10^{-6}$ per recipient cell : $40 \%$ of the $\arg ^{+}$transductants were $\mathrm{Trp}^{-}$and $11 \%$ of the $i l v D^{+}$transductants were $\mathrm{Met}^{-}$. This indicated that in PAO286(pMO555) both the original auxotrophic alleles were still present and therefore that methionine and tryptophan synthesis was being accomplished by genetic material carried by the prime plasmid.

Thus from its origins and properties pMO555 is a prime plasmid carrying a segment of $\boldsymbol{M}$. methylotrophus AS1 genome which includes a gene for methionine synthesis and three genes for tryptophan synthesis. Hence these four genes are linked on the AS1 genome. There is a problem concerning the nomenclature of the markers identified by the complementation procedure. 
Strictly speaking, all we can identify by this method is the presence of a region in a prime plasmid which can change the phenotype of a given $P$. aeruginosa strain carrying a known marker. We suggest that such regions of the AS1 chromosome are best identified by symbols which do not imply a genotypic identification, but rather a phenotypic characterization. We propose to identify such ASl markers by a prefix C (for complementation) followed by the gene symbol of the $P$. aeruginosa marker complemented.

A range of primes has been isolated using selection for different $P$. aeruginosa PAO markers. The principles of the procedures used were the same as those used to isolate pMO555. The properties of these primes are listed in Table 3.

Several different prime plasmids derived from pMO172 carried in M. methylotrophus AS1 have been transferred to $P$. aeruginosa, where each prime can complement either a single auxotrophic function or a range of auxotrophic functions (Table 3). The simplest explanation of these results is that different regions of the AS1 chromosome are being picked up by different prime plasmids and that the range of functions complemented in $P$. aeruginosa is a direct indication of which wild-type alleles are carried by each AS1 fragment. Thus, the pattern of complementation is a guide to the linkage relationships of ASl genes. On this basis it is possible to construct linkage groups of the markers examined.

If the pattern of complementation of primes is to be effective as a procedure for mapping a number of conditions must be met.

(i) The plasmid generating the primes must be capable of forming primes which carry a wide variety of chromosomal fragments. This aspect of IncP-1 ECM plasmids has not been widely studied but data from $P$. aeruginosa (B. Holloway, unpublished; J. Hill and B. Holloway, unpublished; Morgan, 1982) show that a wide range of different primes can be isolated. The data in Table 3 support the view that a range of primes can be formed in M. methylotrophus AS1.

(ii) The recipient bacterium ( $P$. aeruginosa PAO in this case) must be capable of allowing the expression of the incoming bacterial functions carried by the prime plasmid. We have discussed this aspect of $P$. aeruginosa in a previous paper (Holloway et al., 1979) and there is evidence that a range of functions from $E$. coli, $P$. putida and now $M$. methylotrophus AS1 can be expressed in $P$. aeruginosa. Evidence to show that some functions are not expressed may be more difficult to obtain.

(iii) Auxotrophs play an important part in the selection procedures for the plasmid primes, although other markers can be used. For auxotrophic markers, it must be assumed that the biosynthetic pathways in the organism from which the primes are derived and those in the recipient organism are very similar. In at least one case minor differences are not of consequence, as shown with the tryptophan pathway. A derivative of R68.45 carrying the entire tryptophan operon of $E$. coli can complement all six functions $(\operatorname{trp} A-F)$ of $P$. aeruginosa (Holloway et al., 1980).

(iv) No internal rearrangements occur in the chromosomal fragments carried by prime plasmids. Any deletions, inversions or translocations would reduce the effectiveness of mapping data obtained by this method. There is no evidence that such rearrangements occur in the formation of F prime plasmids in E. coli (Low, 1972) nor that any such rearrangements occur in the formation of $\mathrm{R}$ primes derived from R68.45 in P. aeruginosa (Holloway, 1978; Morgan, 1982; B. Holloway, unpublished).

\section{Construction of linkage groups}

1. Cmet-28, CtrpC, CtrpD, CtrpE, CpyrE. pMO551 complemented trpC only, whereas pMO590 (selection for $C \operatorname{trp} D^{+}$) complemented $\operatorname{trp} C$ and $\operatorname{trpE}$ and pMO592 (selection for $C \operatorname{trp} E^{+}$) complemented $\operatorname{trp} C$ and $\operatorname{trpD}$. Thus $C \operatorname{trp} C, C \operatorname{trpD}$ and $C \operatorname{trp} E$ must be linked to each other. Primes where selection was made for Cmet-28+ (pMO552, pMO555 and pMO574) complemented all three $\operatorname{trp}$ genes, $\operatorname{trp} C, \operatorname{trp} D$ and $\operatorname{trp} E$, indicating that these four genes are clustered. pMO574 also showed the ability to complement pyrE. Thus we can identify a cluster of five markers Cmet-28, CtrpC, CtrpD, CtrpE and CpyrE, but it is not possible to identify their relative order. 
Table 3. Prime plasmids derived from pMO172 and carrying M. methylotrophus AS1 chromosomal fragments as indicated by complementation of $P$. aeruginosa markers

The prime plasmids listed were isolated as described in the text. The marker selected was that of the recipient $P$. aeruginosa $\mathrm{PAO}$ strain used in the initial mating to isolate the prime plasmid. The marker transfer frequency for this marker was estimated by diluting the donor parent carrying the prime and plating measured samples on to minimal medium plus rifampicin, spread with a rifampicin-resistant mutant of the appropriate auxotrophic PAO recipient strain. The donor strain was tested against the range of strains listed in Table 2 to detect any other $P$. aeruginosa PAO auxotrophic markers which could be complemented. The transfer frequency of these other markers was tested in the same way as that for the initial marker used in the selection of the prime.

Prime plasmid and host strain

Marker selected

$\begin{array}{lll}\text { PAO5(pMO551) } & \begin{array}{c}\operatorname{trpC} \\ \text { PAO286(pMO552) } \dagger\end{array} & { }^{*} \text { met-28 } \\ & & 1.0 \times 10^{-2} \\ & & 2.4 \times 10^{-2} \\ \text { PAO12(pMO554) } \dagger & { }^{*} \text { leu-8 } & 3.5 \times 10^{-2} \\ \text { PAO286(pMO555) } \dagger & { }^{*}{ }_{m e t-28} & 3.0 \times 10^{-2} \\ & & \\ \text { PAO898(pMO556) } & \text { ilvD } & 7.0 \times 10^{-2} \\ \text { PAO898(pMO557) } & \text { ilvD } & 2.3 \times 10^{-2} \\ \text { PAO1086(pMO562) } & \text { proB } & 2.9 \times 10^{-2} \\ \text { PAO907(pMO563) } & \text { proA } & 1.3 \times 10^{-1} \\ \text { PAO305(pMO564) } & \text { argG } & 1.3 \times 10^{-1}\end{array}$

PAO896(pMO565)

PAO896(pMO566)

pur -136

pur- 136

PAO325(pMO571)

PAO904(pMO572)

lys-12

$\arg F$

PAO899(pMO574) met-28

$2 \cdot 4 \times 10^{-2}$

PAO462(pMO575)

$\operatorname{trp} A$

$1 \cdot 6 \times 10^{-2}$

PAO462(pMO576)

$\operatorname{trp} A$

PAO90(pMO577)

proC

PAO503(pMO578)

met -9011 donor cell
Transfer frequency of selected marker per

Additional markers carried (as listed in Table 2)

Transfer frequency of other markers per donor cell

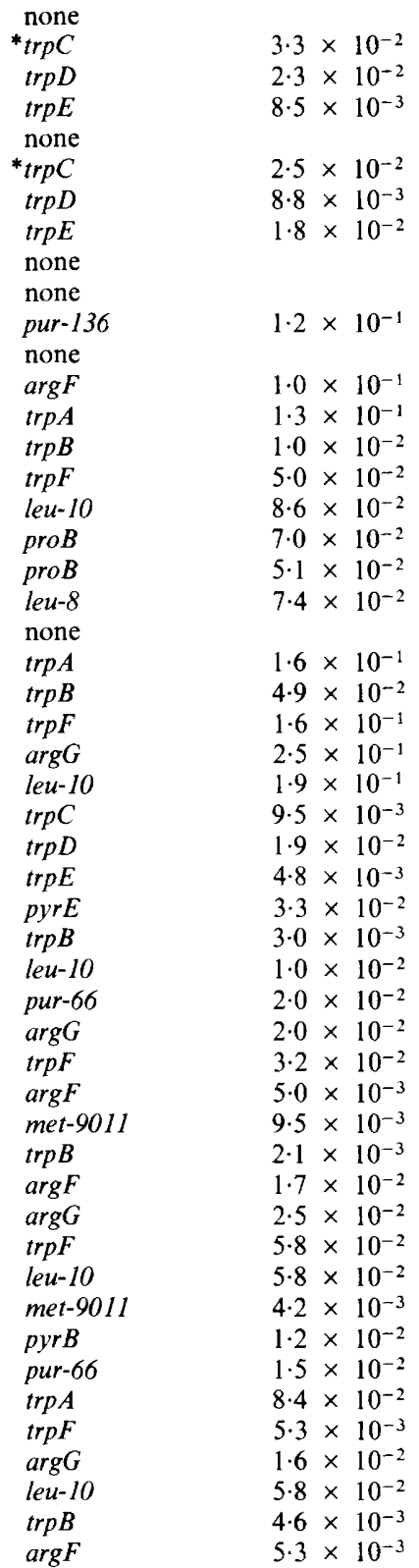




\begin{tabular}{|c|c|c|c|c|}
\hline \multicolumn{5}{|c|}{ Table 3 (continued) } \\
\hline $\begin{array}{l}\text { Prime plasmid and } \\
\text { host strain }\end{array}$ & Marker selected & $\begin{array}{l}\text { Transfer frequency of } \\
\text { selected marker per } \\
\text { donor cell }\end{array}$ & $\begin{array}{l}\text { Additional markers } \\
\text { carried (as listed } \\
\text { in Table 2) }\end{array}$ & $\begin{array}{c}\text { Transfer frequency } \\
\text { of other markers per } \\
\text { donor cell }\end{array}$ \\
\hline PAO897(pMO580) & leu-8 & $2.4 \times 10^{-3}$ & proB & $2.4 \times 10^{-4}$ \\
\hline PAO129(pMO581) & pyrB & $1 \cdot 1 \times 10^{-2}$ & proC & $1.4 \times 10^{-2}$ \\
\hline PAO129(pMO582) & pyrB & $3.1 \times 10^{-2}$ & proC & $4.7 \times 10^{-2}$ \\
\hline PAO325(pMO583) & lys -12 & $1.7 \times 10^{-1}$ & none & \\
\hline PAO1 14(pMO585) & pyrD & $5.9 \times 10^{-3}$ & none & \\
\hline PAO897(pMO586) & pur-66 & $2.9 \times 10^{-1}$ & none & \\
\hline PAO897(pMO587) & $l e u-8$ & $3.5 \times 10^{-1}$ & $\begin{array}{l}\text { proB } \\
\text { pur-136 }\end{array}$ & $\begin{array}{l}2.5 \times 10^{-2} \\
4.2 \times 10^{-2}\end{array}$ \\
\hline PAO900(pMO589) & $i l v B / C$ & $1.3 \times 10^{-2}$ & none & \\
\hline PAO470(pMO590) & $\operatorname{trpD}$ & $1 \cdot 1 \times 10^{-1}$ & $\begin{array}{l}\operatorname{trp} C \\
\operatorname{trp} E\end{array}$ & $\begin{array}{l}1.7 \times 10^{-1} \\
1.5 \times 10^{-1}\end{array}$ \\
\hline PAO472(pMO592) & $\operatorname{trp} E$ & $5 \cdot 3 \times 10^{-2}$ & $\begin{array}{l}\operatorname{trp} C \\
\operatorname{trpD}\end{array}$ & $\begin{array}{l}1.8 \times 10^{-2} \\
1.8 \times 10^{-2}\end{array}$ \\
\hline
\end{tabular}

$\dagger$ These bacterial strains were shown by transduction analysis to carry the $P$. aeruginosa mutant alleles marked *.

2. CproB - Cpur-136 - Cleu-8. Selection for CproB $^{+}$(pMO562), Cpur-136+ (pMO565 and pMO566) and $\mathrm{Cleu}-8^{+}$(pMO587 and pMO580) resulted in five primes which can complement unselected markers, pur-136 in the case of pMO562, pro $B$ with pMO565, proB and leu- 8 with pMO566. pMO587 complements with proB and pur-136 while pMO580 complements only proB. pMO554 (isolated by selection for $\mathrm{Cleu}-8^{+}$) resulted in a prime with no other detectable function cotransferred. From the pattern of markers complemented by these six plasmids the gene order is Cleu-8 - CproB - Cpur-136.

3. $C$ pyr $B-C p r o C-C p u r-66$. Four plasmids had the ability to complement these markers pMO581 and pMO582 (selected for $C p y r B^{+}$and cotransfer of $C p r o C^{+}$), pMO577 (selected for $\mathrm{CproC}^{+}$and cotransfer of $\mathrm{Cpyr}^{+}$and pur-C66+) and pMO586 (selected for $C$ pur- $66^{+}$) which did not complement the other markers. Thus these three markers are linked but their order cannot be determined.

4. Cpur-66-CtrpA-CtrpB-CtrpF-CargG-CargF-Cleu-10-Cmet-9011. This is the largest cluster of linked markers. Five prime plasmids have been isolated which carried all or some of the markers - pMO564 (selected for $C \arg G^{+}$and cotransfer of $\operatorname{CargF}^{+}, C \operatorname{trp} A^{+}, C \operatorname{trpB} B^{+}, C \operatorname{trpF} F^{+}$ and $\mathrm{Cleu}-10^{+}$), pMO578 (selected for Cmet-9011 ${ }^{+}$and cotransfer of $C \operatorname{trp} \mathrm{A}^{+}, \mathrm{CtrpB} \mathrm{B}^{+}, \mathrm{CtrpF} \mathrm{F}^{+}$, $\mathrm{CargG}^{+}, \mathrm{CargF}^{+}$and $\mathrm{Cleu}-10^{+}$), pMO572 (selected for $\mathrm{CargF}{ }^{+}$with cotransfer of $\mathrm{CtrpA^{+ }}$, $\mathrm{CtrpB}^{+}, \mathrm{CtrpF}^{+}, \mathrm{CargG}^{+}$and $\left.\mathrm{Cleu}-10^{+}\right)$. pMO575 and pMO576 were isolated with selection for

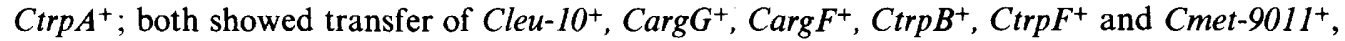
but pMO575 also cotransferred $C p u r-66^{+}$. The gene Cpur-66 must be at one end of this group with Cmet-9011 at the other. The precise order of the intervening genes cannot be determined from the present data. On the basis solely of pMO575 which includes Cpur-66, this group of markers is linked to the previous group $C p y r B-C p r o C-C p u r-66$.

Several single markers have been shown to be carried by other primes. These include pMO563 CproA, pMO556 and pMO557 CilvD, pMO571 and pMO583 Clys-12, pMO585 CpyrD and pMO589 CilvB or CilvC (Table 3). Primes have been sought for other markers without success (Table 2).

\section{Physical analysis of pMO172 and the prime plasmids}

It was first shown by Jacob et al. (1977) that R68 and R68.45 differed in molecular structure in that the latter had acquired an additional $2 \cdot 1-2 \cdot 4 \mathrm{~kb}$ segment of DNA. This additional DNA segment is inserted near the determinant for kanamycin resistance (Riess et al., 1980) and is a duplication of a pre-existing R68 DNA sequence called ISP (Riess et al., 1980). Willetts et al. (1981) have shown that a portion of the tandem duplication is a transposable genetic element identified as IS21. The ECM plasmid pMO61 has been derived in a similar fashion to R68.45 and has essentially the same biological properties (Holloway et al., 1979). Within the limits of restriction enzyme analysis pMO61 is identical to R68.45 in that it carries the same $2 \cdot 1 \mathrm{~kb}$ direct 


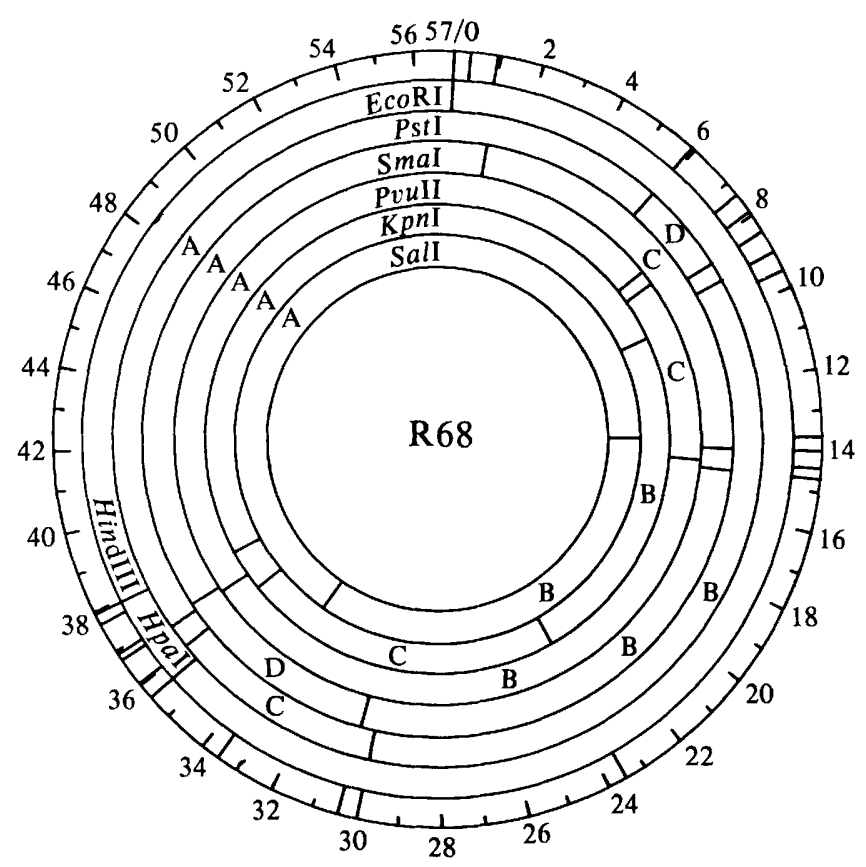

Fig. 1. Restriction enzyme map of the plasmid R68. The single EcoRI site is arbitrarily assigned as $0 \mathrm{~kb}$ and the cleavage sites of a number of restriction enzymes relevant to this study are indicated relative to this site. The KpnI and PstI sites at $36.0 \mathrm{~kb}$ and the $P$ st I and $P v u I I$ sites at $36.8 \mathrm{~kb}$ are not ordered. The outer circle is a composite of all the cleavage sites, which are shown separately for each enzyme in the inner circles.

repeat in the same location (Riess et al., 1980; Willetts et al., 1981). Plasmid DNA preparations of R68 and R68.45 were made from derivatives of the $E$. coli K 12 strain JP2314 and the ECM plasmids pMO61 and pMO172 were isolated from P. aeruginosa PAO8 and P. putida PPN1089. A comparison of the restriction enzyme pattern, after digestion with the restriction enzyme $P$ st $I$ (Fig. 3, tracks 6 and 7) indicates that R68.45 differs from R68 in having a unique $1.35 \mathrm{~kb}$ fragment. There is also an internal $0.75 \mathrm{~kb} \mathrm{R} 68 P_{s t} \mathrm{I}$ fragment which is duplicated in R68.45 (Riess et al., 1980). A comparison of pMO172 with R68.45 (Fig. 3, tracks 5 and 6) shows that they have identical PstI fragments. Digestion of pMO172 with the restriction enzymes SmaI, $K p n I, P v u I I$ and $H p a I$ produced the $2.1 \mathrm{~kb}$ fragment characteristic of the duplication and there was no difference in restriction patterns when compared with R68.45. Thus within the limits of restriction enzyme analysis there was no detectable difference between pMO172, its parent pMO61, and R68.45.

The prime plasmids pMO551 and pMO564 were isolated from derivatives of $P$. aeruginosa PAO5 and PAO305. Digestion of pMO551 with the restriction enzymes EcoRI and HindIII, both of which have a single restriction enzyme site on pMO172 (Fig. 1), showed that pMO551 has acquired two additional HindIII and EcoRI sites (data not shown). This indicates that there has been an addition of DNA in pMO551 compared with its parent pMO172. The additional DNA is inserted into the smallest $6.5 \mathrm{~kb}$ HindIII-SalI fragment since this was absent in a HindIII/SalI double digest. The additional DNA was further localized to the $2 \cdot 1 \mathrm{~kb} H p a I$ fragment of pMO172 since this was lost in an HpaI digest of pMO551 (Fig. 3, tracks 3 and 4). Since the characteristic $2 \cdot 1 \mathrm{~kb} S m a \mathrm{I}, P v u \mathrm{II}, H p a \mathrm{I}$ and $K p n I$ fragments were also lost in pMO551, compared with its parent pMO172, the chromosomal segment is inserted somewhere between the HpaI site of the left-hand copy of the duplicated portion and the SmaI site of the right-hand copy (Fig. 2). Leemans et al. (1980) have suggested that the chromosomal segment of a prime plasmid is inserted between the two copies of the direct repeat. However, this explanation cannot hold for pMO551 since in a PstI digestion of pMO551 there was a loss of the $1.35 \mathrm{~kb}$ 


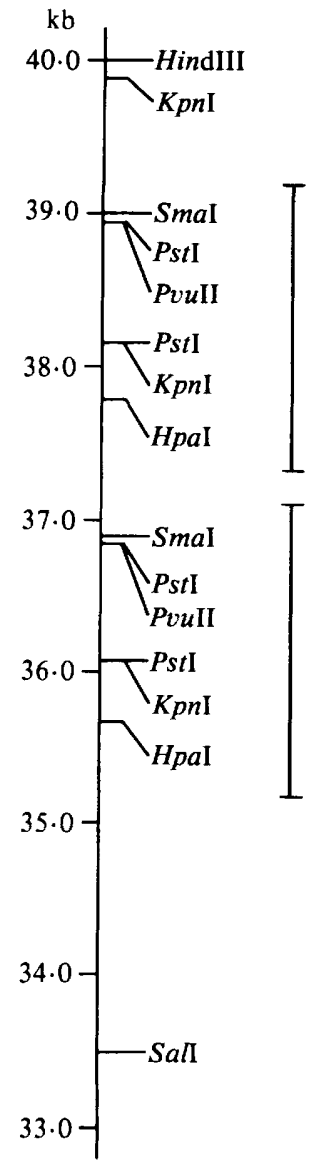

Fig. 2. Restriction map of the $6.5 \mathrm{~kb}$ HindIII-SalI region of $\mathrm{R} 68.45$ containing the DNA duplication. The order of the Pst I and PvuII sites at 36.8 and $38.9 \mathrm{~kb}$ and the Pst I and KpnI sites at 36.0 and $38.1 \mathrm{~kb}$ could not be determined. The bar lines indicate the restriction sites of the duplicate segments.

unique fragment as well as two new fragments of $2.2 \mathrm{~kb}$ and $1.0 \mathrm{~kb}$ in addition to an increase in the molecular weight of PstI fragment C. Similarly in a SmaI digestion of pMO551 there was a loss of the characteristic $2.1 \mathrm{~kb}$ fragment, generation of a new fragment of $3.4 \mathrm{~kb}$ and an increase in the molecular weight of SmaI fragment D. Thus the area adjoining the direct repeat, covered by PstI fragment C and SmaI fragment D (Fig. 1), has also been altered by the insertion. A double insertion event can be ruled out since in a KpnI digestion of pMO551 there was a loss of the characteristic $2.1 \mathrm{~kb}$ fragment, and an increase in the molecular weight of $K p n I$ fragment C, but no new KpnI fragments were generated. The simplest explanation of these results is that the chromosomal segment has inserted into the duplicated region and in this process, or subsequently, there has been a deletion of part or all of one of the copies of the duplicated segment. There is a precedent for this hypothesis since it has been observed in other ECM plasmids that a single copy of the duplicated segment can excise precisely and leave behind the other copy of the sequence (W. Schurter \& B. W. Holloway, unpublished). Assuming there has been a precise deletion of one copy of the duplicated segment in pMO551, the size of the $M$. methylotrophus DNA insertion would be $4.8 \mathrm{~kb}$.

Digestion of pMO564 with the restriction enzymes HindIII and EcoRI indicated that it had acquired a minimum of eight new EcoRI and 14 new $H$ indIII restriction enzyme sites. The acquisition of a large number of restriction enzyme sites is indicative of a DNA insertion in 


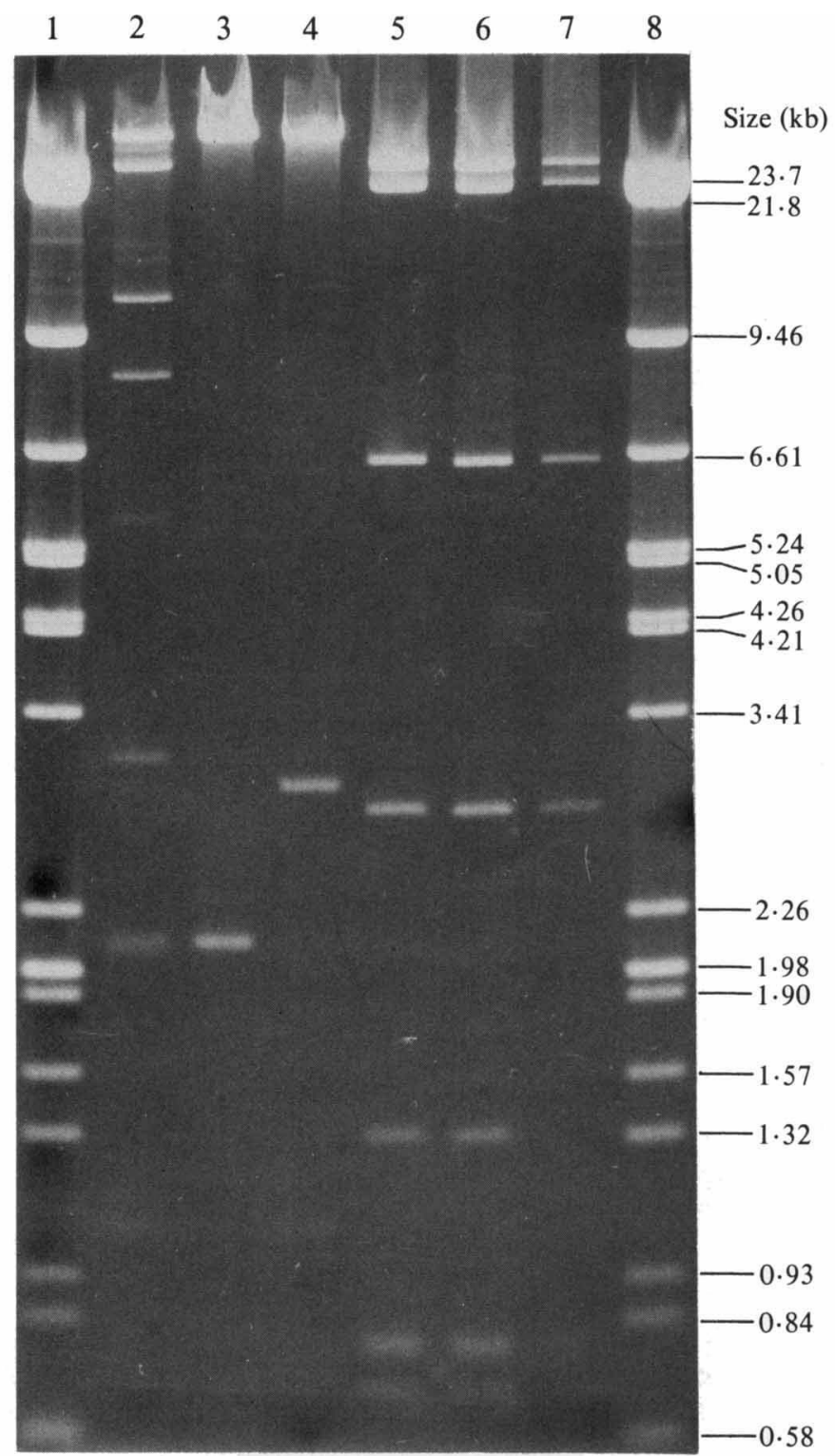

Fig. 3. Restriction enzyme cleavage of R68, R68.45, pMO172, pMO551 and pMO564. Tracks 1 and 8 contain $\lambda$ HindIII and $\lambda$ HindIII/EcoRI fragments used for size standards; the other tracks contain HpaI digestion of pMO564 (track 2), pMO1 72 (track 3) and pMO551 (track 4), and PstI digestion of pMO172 (track 5), R68.45 (track 6) and R68 (track 7).

pMO564, compared with its parent pMO172. Due to the large size of the DNA addition it was only possible to estimate its size approximately. Comparison of the $\mathrm{HpaI}$ fragments of pMO564 with those of its parent pMO172 (Fig. 3, tracks 2 and 3) indicated that the size of the DNA addition was between 75 and $100 \mathrm{~kb}$. The large size of the insertion also led to the generation of a large number of restriction fragments when the plasmid was digested with a range of restriction enzymes, so it was not possible to determine the location of the insertion. The relative size of the DNA additions in pMO551 and pMO564 correlates well with the pattern of markers of $P$. aeruginosa complemented by each plasmid; pMO551 carries a small DNA addition of approximately $4.8 \mathrm{~kb}$ and complements one $P$. aeruginos $a$ marker while pMO564 carries a much larger DNA addition and can complement five $P$. aeruginosa markers (Table 3). 

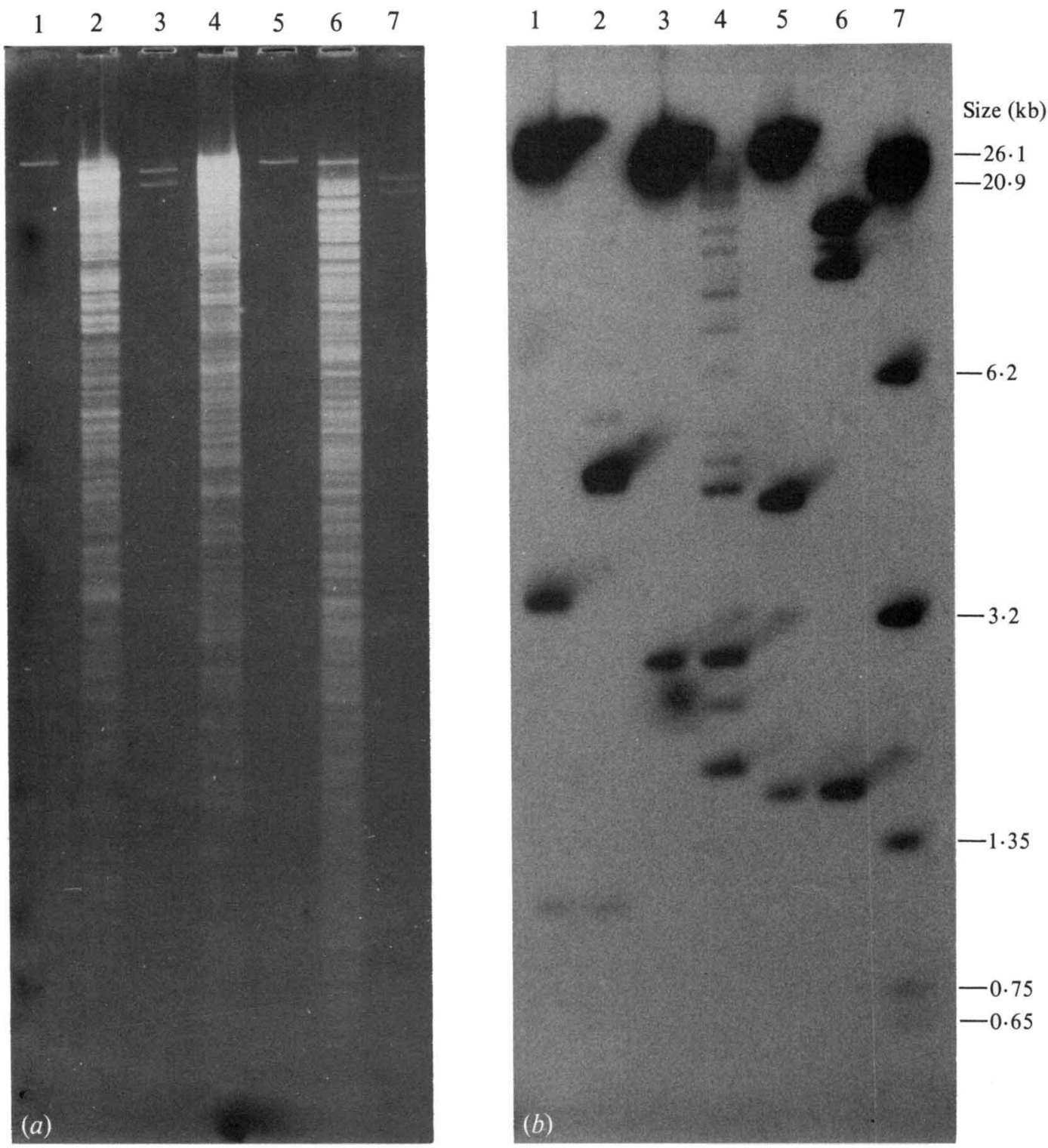

Fig. 4. (a) Restriction enzyme digests of $M$. methylotrophus ASl total bacterial DNA with $H$ paI (track 2), EcoRI (track 4) and HindIII (track 6). Tracks 1, 3 and 5 contain $0.01 \mu$ g pMO551 digested with $H$ paI (track 1), EcoRI (track 3) or HindIII (track 5), and track 7 contains $0.01 \mu$ g pMO1 72 digested with PstI. (b) Autoradiogram of hybridization of the probe pMO551 to the tracks described in $(a)$.

Southern hybridization to determine the origin of the additional DNA in the prime plasmids

Southern hybridization experiments were used to provide information on the origin of the additional DNA segments of pMO551 and pMO564. Total bacterial DNA was isolated from $M$. methylotrophus AS1 then digested separately with $H p a \mathrm{I}$, EcoRI or HindIII and examined by the procedure of Southern (1975). The plasmid DNA used for this experiment was isolated from $P$. aeruginosa or $P$. putida to avoid any contamination with $M$. methylotrophus AS1 chromosomal DNA.

When the pMO172 probe was hybridized to $M$. methylotrophus AS1 chromosomal DNA fragments, no evidence of homology was observed even after prolonged exposure of the 


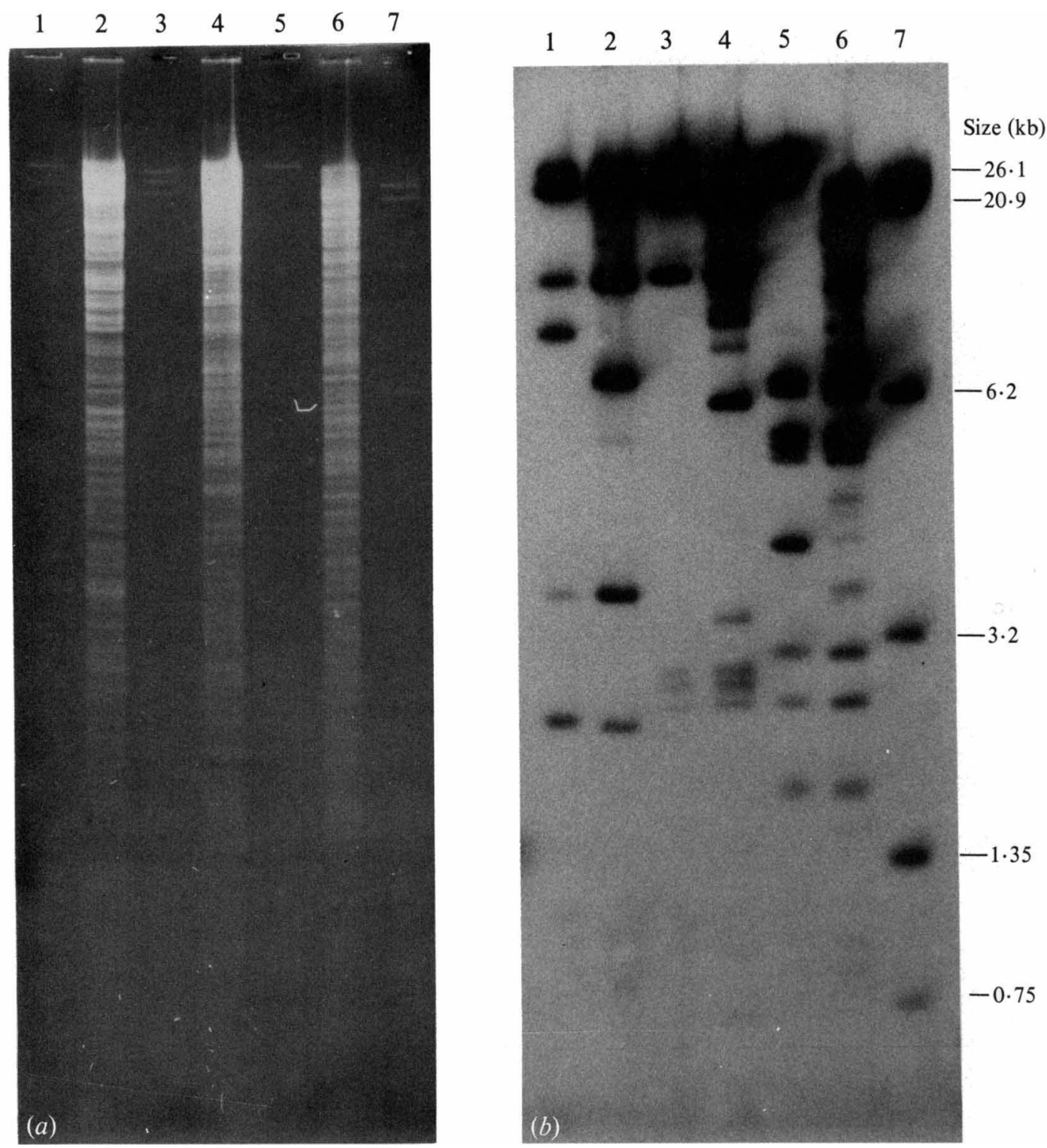

Fig. 5. (a) Restriction enzyme digests of $M$. methylotrophus AS1 total bacterial DNA with HpaI (track 2), EcoRI (track 4) and HindIII (track 6). Tracks 1, 3 and 5 contain $0 \cdot 01 \mu \mathrm{g}$ pMO564 digested with HpaI (track 1), EcoRI (track 3) or HindIII (track 5), and track 7 contains 0.01 $\mu$ g pMO172 digested with PstI. (b) Autoradiogram of hybridization of the probe pMO564 to the tracks described in $(a)$.

autoradiogram. A control track containing $0.01 \mu \mathrm{g}$ pMO172 DNA digested with PstI showed strong hybridization (results not shown). There are thus no common sequences between pMO172 and the $M$. methylotrophus AS1 genome. However, hybridization of the pMO551 (Fig. $4 b$, tracks 2, 4 and 6) and pMO564 (Fig. $5 b$, tracks 2, 4 and 6) plasmid DNA probes to the $M$. methylotrophus AS1 DNA fragments showed that regions of homology exist. Since pMO172 has no sequence homology with $M$. methylotrophus AS1 DNA, it can be concluded that the prime plasmids pMO551 and pMO564 carry a segment of the $M$. methylotrophus AS1 genome. In the case of pMO551 there is a $1.1 \mathrm{~kb}$ internal $\mathrm{HpaI}$ fragment (Fig. $4 b$, tracks 1 and 2), a $2.65 \mathrm{~kb}$ internal Eco RI fragment (Fig. $4 b$, tracks 3 and 4 ) and a $2.0 \mathrm{~kb}$ internal HindIII fragment (Fig. 
$4 b$, tracks 5 and 6) which are unchanged in the DNA segment carried by the prime plasmid, compared with the $M$. methylotrophus AS1 chromosome. pMO564 has a minimum of three internal $H p a \mathrm{I}$ fragments (Fig. $5 b$, tracks 1 and 2), four internal $E c o$ RI fragments (Fig. $5 b$, tracks 3 and 4) and eight internal HindIII fragments (Fig. 5b, tracks 5 and 6) which are unchanged in the DNA segment carried by it, compared with the $M$. methylotrophus AS1 genome. The comparison of such internal fragments shows there is identity between the segment carried by the prime plasmid and the $M$. methylotrophus AS1 DNA. In a number of cases where hybridization was carried out to $M$. methylotrophus AS1 DNA fragments (Fig. $4 b$, track 4 and Fig. $5 b$, tracks 4 and 6) weaker bands of hybridization, especially to larger molecular weight fragments, were observed. These are most likely to be partial digest fragments and were even observed after prolonged incubation (minimum of $8 \mathrm{~h}$ ) of the restriction enzyme digestion.

\section{DISCUSSION}

We have isolated a variety of prime plasmids which carry sections of Methylophilus methylotrophus AS1 chromosome. The evidence for this view can be summarized as follows. (i) When the prime plasmid is transferred to an appropriate $P$. aeruginosa PAO strain it can complement a specific range of auxotrophic markers ranging, for different prime plasmids, from one to eight auxotrophic functions. This complementation ability and the antibiotic resistance markers carried by the plasmid are transferred at similar frequencies. (ii) Physical analysis of two of these prime plasmids showed they had acquired an additional DNA segment and Southern hybridization experiments demonstrated that this additional DNA was a segment of M. methylotrophus AS1 DNA.

The isolation of this type of plasmid from M. methylotrophus AS1 has an added interest because it provides a means of mapping the genes of that organism. Mapping of $M$. methylotrophus AS1 is intrinsically difficult because auxotrophic mutations of this organism are very difficult to isolate. Furthermore, mobilization of chromosomal genes by ECM plasmids occurs at a low frequency (Holloway, 1981) and as yet no transducing bacteriophage has been found for any methylotrophic bacterium.

The essential features of our mapping procedure are thus the formation of primes carrying $M$. methylotrophus AS1 DNA; the need for a wide range of such primes, covering most, if not all of the genome; the ability of such prime plasmids to transfer to $P$. aeruginosa; and the expression of the encoded functions in that bacterium. This last feature is detected by complementation of $P$. aeruginosa PAO functions absent from mutant strains. To date only auxotrophic markers have been complemented but there is no reason why other functions should not be complemented. Indeed this may be a procedure for identifying metabolic functions of $M$. methylotrophus AS1 for which mutants cannot, for one reason or another, be isolated. It should be possible to use recipients other than $P$. aeruginosa for detecting such functions.

It can be concluded from the range of primes isolated that there is variation in the size of DNA fragment incorporated into the prime plasmids. This is an advantage to the method in that such variations help to identify adjoining genes in the same way that deletions of different length permit deletion mapping.

Pseudomonas aeruginosa has a variety of features which make it an attractive recipient for this type of mapping. Firstly, there is increasing evidence that DNA from other bacteria is expressed readily in $P$. aeruginosa. Secondly, the lack of clustering of auxotrophic markers in $P$. aeruginosa, compared with that found in enteric bacteria, means that the chance of detecting cotransferred functions is higher. There are now over 100 genes mapped in $P$. aeruginosa $P A O$ and the number is increasing. Finally, the so-called ' $43^{\circ} \mathrm{C}$ effect' by which restriction endonuclease action can be reduced to aid the entry of foreign DNA greatly increases the chance of successful prime plasmid establishment.

The choice of pMO172 as the generator of M. methylotrophus AS1 plasmid primes was to some extent fortuitous and we have not examined the prime-forming ability of other ECM plasmids. Preliminary experiments (B. Holloway \& W. Schurter, unpublished) have shown that different ECM plasmids differ in the ease with which they can form prime plasmids. The possibility exists 
that ECM plasmids can be isolated which can form primes more frequently than those already tested for this ability, such as R68.45 and pMO172. As yet little is known of the mechanism by which prime plasmids are derived from ECM plasmids. There is some evidence (Leemans et al., 1980 ; N. Willetts \& C. Crowther, unpublished) that the single copies of IS 21 flank the inserted piece of chromosomal DNA, but more data are needed to substantiate this.

Further experiments need to be done to expand the present findings. These include the demonstration of $M$. methylotrophus ASl enzyme activity in the complemented $P$. aeruginosa recipient and an examination of the regulatory pattern of such enzymes. It will be interesting to define the range of bacteria which can complement $M$. methylotrophus functions effectively. Identification of a range of functions of $M$. methylotrophus in this manner could be of considerable interest in demonstrating the metabolic pathways which occur in that organism and establishing whether any metabolic functions are dormant or repressed.

This work was supported by Imperial Chemical Industries. The technical assistance of Robyn Bray is gratefully acknowledged.

\section{REFERENCES}

Calhoun, D. H., Pierson, D. L. \& Jensen, R. A. (1973). The regulation of tryptophan biosynthesis in Pseudomonas aeruginosa. Molecular and General Genetics 121, 117-132.

HaAs, D. \& Holloway, B. W. (1976). R factor variants with enhanced sex factor activity in Pseudomonas aeruginosa. Molecular and General Genetics 144, 243 251.

HollowaY, B. W. (1965). Variations in restriction and modification following increase of growth temperature of Pseudomonas aeruginosa. Virology 25, 634642.

Holloway, B. W. (1978). Isolation and characterisation of an $\mathrm{R}^{\prime}$ plasmid in Pseudomonas aeruginosa. Journal of Bacteriology 133, 1078-1082.

Holloway, B. W. (1979). Plasmids that mobilize bacterial chromosome. Plasmid 2, 1-19.

Holloway, B. W. (1981). The application of pseudomonad-based genetics to methylotrophs. In Microbial Growth on $C_{1}$ Compounds. Proceedings of the Third International Symposium, Sheffield, pp. 317324. Edited by H. Dalton. London: Heyden \& Son.

Holloway, B. W. \& Crockett, R. J. (1982). Pseudomonas aeruginosa. Genetic Maps 2, 165-167.

Holloway, B. W. \& Van de Putte, P. (1968). Lysogeny and bacterial recombination. In Replication and Recombination of Genetic Material, pp. 175183. Edited by W. J. Peacock \& R. D. Brock. Canberra: Australian Academy of Science.

Holloway, B. W., Krishnapillai, V. \& MorGan, A. F. (1979). Chromosomal genetics of Pseudomonas. Microbiological Reviews 43, 73-102.

Holloway, B. W., Crowther, C., Royle, P. \& NAYUdU, M. (1980). R-plasmids and bacterial chromosome transfer. In Antibiotic Resistance, Transposition and Other Mechanisms. Fourth Symposium on Antibiotic Resistance, Smolenice, pp. 19-27. Edited by S. Mitsuhashi, L. Rosival \& V. Krcmery. Prague: Avicenum

ISAAC, J. H. \& Holloway, B. W. (1968). Control of pyrimidine biosynthesis in Pseudomonas aeruginosa. Journal of Bacteriology 96, 1732-1741.

IsaAC, J. H. \& Holloway, B. W. (1972). Control of arginine biosynthesis in Pseudomonas aeruginosa. Journal of General Microbiology 73, 427-438.
JACOB, A. E., Creswell, J. M. \& Hedges, R. W (1977). Molecular characterization of the $\mathbf{P}$ group plasmid R68 and variants with enhanced chromosomal mobilizing ability. FEMS Microbiology Letters 1, 71-74.

Johnston, A. W. B., Setchell, S. M. \& Beringer, J. E. (1978). Interspecific crosses between Rhizobium leguminosarum and $R$. meliloti: formation of haploid recombinants and of R-primes. Journal of General Microbiology 104, 209-218.

KRISHNAPILlaI, V. (1971). A novel transducing phage. Its role in recognition of a possible new hostcontrolled modification system in Pseudomonas aeruginosa. Molecular and General Genetics 114, 134 143.

Leemans, J., Villarroel, R., Silva, B., van MonTAGU, M. \& SChEll, J. (1980). Direct repetition of a 1.2 md DNA sequence is involved in site specific recombination by the $\mathrm{P} 1$ plasmid $\mathrm{R} 68$. Gene 10,319 328.

LeVINTHAL, M. (1974). Bacterial genetics excluding $E$. coli. Annual Review of Genetics 8, 219-230.

Low, K. B. (1972). Escherichia coli K12 F-prime factors, old and new. Bacteriological Reviews 36, 587607.

Morgan, A. F. (1979). Transduction of Pseudomonas aeruginosa with a mutant of bacteriophage E79. Journal of Bacteriology 139, 137-140.

MORGAN, A. F. (1982). Isolation and characterization of Pseudomonas aeruginosa $\mathbf{R}^{\prime}$ plasmids constructed by means of interspecific mating. Journal of Bacteriology 149, 654-661.

Nagahari, K., Sano, Y. \& Sakaguchi, K. (1977). Derepression of $E$. coli trp operon on interfamilial transfer. Nature, London 266, 745-746.

Nayudu, M. \& Holloway, B. W. (1981). Isolation and characterisation of $\mathrm{R}$ plasmid variants with enhanced chromosomal mobilisation ability in $E$. coli K12. Plasmid 6, 53-65.

O'Connor, M. L. \& Hanson, R. S. (1978). Linkage relationships between mutants of Methylobacterium organophilum impaired in their ability to grow on one-carbon compounds. Journal of General Microbiology 104, 105-111.

Pemberton, J. M. \& Holloway, B. W. (1972). 
Chromosome mapping in Pseudomonas aeruginosa. Genetical Research 19, 251-260.

Pemberton, J. M. \& Holloway, B. W. (1973). A new sex factor of Pseudomonas aeruginosa. Genetical Research 21, 263-272.

Riess, G., Holloway, B. W. \& PüHler, A. (1980). R68.45, a plasmid with chromosome mobilizing ability (Cma), carries a tandem duplication. Genetical Research 36, 99-109.

Royle, P. L. \& Holloway, B. W. (1980). Relationship between R and FP plasmids in Pseudomonas aeruginosa. Antimicrobial Agents and Chemotherapy 17, 293-297.
Southern, E. (1975). Detection of specific sequences among DNA fragments separated by gel electrophoresis. Journal of Molecular Biology 98, 503-517.

Willetts, N. S., Crowther, C. \& Holloway, B. W. (1981). The insertion sequence IS21 of R68.45 and the molecular basis for mobilization of the bacterial chromosome. Plasmid 6, 30-52.

Windass, J. D., Worsey, M. J., Pioli, E. M., Pioli, D., Barth, P. T., Atherton, K. T., Dart, E. C., Byrom, D., Powell, K. \& Senior, P. K. (1980). Improved conversion of methanol to single-cell protein by Methylophilus methylotrophus. Nature, London 287, 396-401. 